\title{
HUMIC ACID STIMULATION OF GROWTH AND OPTIMIZATION OF BIOCHEMICAL PROFILES IN TWO MICROALGAL SPECIES PROPOSED AS LIVE FEEDS IN AQUACULTURE.
}

\author{
Nagwa Gamal-EIDin Mohammady \\ Department of Botany, Faculty of Science, Muharram Beck, Alexandria \\ University, Alexandria, Egypt.
}

\begin{abstract}
A series of batch culture experiments of two marine microalgae Dunaliella salina Teodoresco and Nannochloropsis salina Hibberd was conducted at various humic acid (HA) concentrations $\left(0.0,0.1,0.2,0.3,0.4,0.5 \mathrm{mgL}^{-1}\right)$ to evaluate the stimulatory potential of HA on the growth (expressed as a biomass concentration), pigment production (chlorophyll $a$ and carotenoids) and $\mathrm{C} / \mathrm{N}$ ratio. The impact of HA on the proximate composition (moisture, ashes, dietary fiber, crude lipid, available carbohydrates, crude protein and the energy content) was also considered. Results demonstrated a highly significant positive effect of HA on growth, pigment production and proximate analysis $(P \leq 0.01)$. The response of both investigated microalgae to HA show optima in the range of concentration studied, which makes it a low cost-high yield investment. However, C/N ratio in D. salina showed a gradual decrease upon addition of HA. On the other hand a slight increase in the ratio was observed in N. salina.
\end{abstract}

Keywords: Biochemical profiles, Growth, Humic acid, Microalgae, D. salina, N. salina

\section{Introduction}

Microalgae have an important role in aquaculture as a means of enriching zooplankton for on-feeding to fish and other larvae. In addition to providing energy which is transferred through the food chain to higher trophic levels via the zooplankton intermediates. (Brown, 2002). They are characterized by high nutrient production such as proteins, lipids, carbohydrates (Renaud et al., 1999); sterols (Mohammady, 2004); polyunsaturated fatty acids (Sargent et al., 1997) and minerals (Fabregas and Herrero, 1986).The biochemical composition of microalgae can be manipulated readily by changing the growth conditions (Brown et al., 1997). Nutrient enrichment and optimization is one of these conditions of practical use to aquaculturists who may then grow microalgae to optimize the level of specific nutrient (s) needed by the feeding animal. The enrichment of microorganism's nutrient medium by humic substances (HS) was studied (MullerWegener, 1988). This organic matter is commonly distributed in the natural habitats such as water, soil and sediments (Coates et al., 2002). It is easily available as compost (Canellas et al., 2002) for conducting to different crops (Mackowiak et al., 2001; Canellas et al., 2002) in support of their highly 
recognized benefits, which are attributed to the numerous functional groups that HS are characterized (Coates et al., 2002). HS have been extensively studied for their possible contribution to phytoplankton growth as a source of nitrogen (Carlsson et al., 1995) and carbon (Doblin et al., 1999). Other studies (Doblin et al., 2000) attributed the benefits of humic substances to microalgae for the reason that they act as metal-bending ligands that modulate the availability of trace elements. Furthermore, a combination of metabolic (Doblin et al., 1999) and membrane permeability alterations (Vigneault et al., 2000) triggered by HS might also enhance algal growth.

Humic acid (HA) is a fraction of HS; which has a variety of chemical functions (Sun et al., 2005). It has been shown to positively affect the growth rate and biomass production of Chlorella vulgaris (Brown, 1969), the dinofagellate Alexanderium tamarense (Gagnon et al., 2005) and some diatom species (Granéli et al., 1999).

Dunaliella (Dunal) salina Teodoresco is a marine microalgae used in aquaculture industry as live feeds for copepods Acartia tonsa (Veloza et al., 2006). While Nannochloropsis (Monallantus) salina Hibberd is used for both Brachionis plicatilis and Artemia spp. (Brown et al., 1997; Brown, 2002). Both species have a nanoplankton size $(2-20 \mu \mathrm{m})$ with a cellular composition of high nutritional value (Brown et al., 1997). They have extensive production of valuable pigments (Fried, et al., 1982, Lubián et al., 2000) and polyunsaturated fatty acids (Fried, et al., 1982; Sukenik et al., 1989). Therefore, the objective of this study is to evaluate the stimulatory potential of HA extracted from garden soil for increasing biomass and improving different biochemical profiles of $D$. salina and N. salina. Mohammady and Fathy (2007) showed that HA has no effect on fatty acid composition of these two strains. So data were provided on biomass concentration, pigments (chlorophyll $a$ and carotenoids), $\mathrm{C} / \mathrm{N}$ ratio and the proximate components (moisture, ash, dietary fibers, crude lipid, available carbohydrates, crude protein and the energy content).

\section{Materials and Methods}

\section{Extraction of humic acid (HA):}

From the top $6 \mathrm{~cm}$ of garden soil of Faculty of Science, Alexandria University; sample was freshly collected and transported directly back to the algae laboratory, where it was immediately assayed for HA extraction according to Stevenson (1982). In brief, A $25 \mathrm{~g}$ sample of sieved uncontaminated garden soil was allowed to settle, the aqueous-phase material was decanted and discarded. Approximately $25 \mathrm{~mL}$ of water was added to the soil and the slurry was allowed to sit for $30 \mathrm{~min}$. The $\mathrm{pH}$ was then adjusted to 7.0 with the addition of $1 \mathrm{M} \mathrm{NaOH}$. The total volume of the slurry was brought to $250 \mathrm{~mL}$ with the addition of $0.1 \mathrm{M} \mathrm{NaOH}$, and the mixture was stirred for $24 \mathrm{~h}$. The mixture was 
then centrifuged and the particle-free supernatant was adjusted to $\mathrm{pH} 1.0$ by adding $6 \mathrm{M} \mathrm{HCl}$ with constant stirring. This resulted in the formation of a dark brown precipitate. The suspension was allowed to stand for $12 \mathrm{~h}$ and centrifuged to recover the precipitate, this precipitate was suspended in a solution of $0.1 \mathrm{M}$ $\mathrm{HCl}$ and $0.3 \mathrm{M} \mathrm{HF}$ overnight to remove minerals impurities and then washed with distilled water to remove chlorides. The sample was then centrifuged and the precipitated HA was freeze dried and stored in desiccator. HA was examined using infrared analysis, unpublished data.

\section{Microalgae and culture media:}

The chlorophyte Dunaliella salina was obtained from the algal culture collection of the Faculty of Science, Alexandria University, Egypt. The cultures were grown axenically in 1L MH medium according to Loeblich (1982). The eustigmatophyte Nannochloropsis salina was obtained from the Solar Energy Research Institute (SERI) Culture Collection in Golden, Colorado, USA. The cultures were grown axenically in enriched seawater according to Boussiba et al. (1987). Stock HA was added to the culture medium to yield the following final concentrations: $0.0,0.1,0.2,0.3,0.4$ and $0.5 \mathrm{mgL}^{-1}$.

\section{Culture conditions:}

All cultures were grown in triplicate $1 \mathrm{~L}$ glass flasks equipped with inlet and outlet tubes for aeration in a temperature controlled room at $23 \pm 1{ }^{\circ} \mathrm{C}$. Cultures were continuously agitated by bubbling with sterile air, which was also enriched with $0.5 \% \mathrm{CO}_{2}$. Illumination was provided by fluorescent lamps with an irradiance of $300 \mu \mathrm{mol} \mathrm{m}^{-2} \mathrm{~s}^{-1}$ at the surface of the cultures under a 16: 8-h light: dark regime.

\section{Biomass recovery and estimation:}

According to (Mirón et al., 2002), the cultures were daily recovered by introducing the suspensions into a continuous centrifuge (JANETZKI T24) running at $1000 \mathrm{x} g$ for $5 \mathrm{~min}$. The harvested cells were washed with saline water $(0.5 \mathrm{M} \mathrm{NaCl})$ and the optical density of the suspension was determined spectrophotometrically at $625 \mathrm{~nm}$, using a Perkin Elmer Spectrophotometer, Lambadal. Biomass concentration $\left(\mathrm{C}_{\mathrm{b}}, \mathrm{gL}^{-1}\right)$ was calculated as following: $\mathrm{C}_{\mathrm{b}}=0.38$ $\mathrm{x} \mathrm{OD}_{625}$. A growth curve has been established for each alga.

\section{The exponentially grown cultures were subjected to the following analyses:}

\section{Chlorophyll a}

The spectrophotometric method of Hansmann (1973) was used for estimating chlorophyll $a$ content in the algal cells. The optical density of the suspension was determined at 665, 645 and $630 \mathrm{~nm}$ using a Perkin Elmer Spectrophotometer, Lambadal. The concentration of chlorophyll $a\left(\mathrm{mgL}^{-1}\right)$ was calculated as following: 
$\mathrm{Ch}_{a}=11.6 \times \mathrm{OD}_{665}-1.31 \times \mathrm{OD}_{645}-0.14 \times \mathrm{OD}_{630}$. Data were standardized as a dry weight biomass.

\section{Total carotenoids}

Carotenoids were determined according to the method of Whyte (1987). The optical density of the suspension was determined at $444 \mathrm{~nm}$ wavelength using a Perkin Elmer Spectrophotometer, Lambadal. The concentration of total carotenoid $\left(\mathrm{mgL}^{-1}\right)$ was calculated as following: $\mathrm{C}_{\mathrm{t}}=4.32 \times \mathrm{OD}_{444}-0.0439$. Data were standardized as a dry weight biomass.

\section{Carbon and Nitrogen}

The harvested cells were introduced into the Elemental Analyzer PE2400 Series II CHNS/O and C/N ratio was calculated.

\section{Proximate composition:}

The following analyses were individually proceeded as a component of the proximate composition.

\section{Moisture}

The moisture was determined by drying a representative $2 \mathrm{~g}$ sample of the pellet in an oven at $100-105{ }^{\circ} \mathrm{C}$ for $40 \mathrm{~h}$ (Rebolloso Fuentes et al., 2000).

\section{Ashes}

Total ash was determined by incineration of a representative $0.5 \mathrm{~g}$ sample of the pellet in an oven at $450{ }^{\circ} \mathrm{C}$ for $48 \mathrm{~h}$ (Rebolloso Fuentes et al., 2000).

\section{Dietary fibers}

Fibers were determined by the neutral detergent extraction procedure (Goering and Van Soest, 1970).

\section{Crude lipid}

According to Kochert (1978), lipid was determined on the weighed extract obtained with chloroform/methanol $(2: 1, \mathrm{v} / \mathrm{v})$.

\section{Available carbohydrates}

The anthrone-sulfuric acid method was applied according to Osborne (1985). A calibration curve was prepared to each experiment using D glucose dissolved in distilled water. The glucose concentration $\left(\mathrm{C}_{\mathrm{g}}, \mathrm{mgL}^{-1}\right)$ was calculated from the optical density at $630 \mathrm{~nm}$ according to the following equation: $\mathrm{C}_{\mathrm{g}}=0.536$ $\mathrm{x} \mathrm{OD}_{630}+0.0028$.

\section{Crude protein}

Total protein was calculated by multiplying the $\mathrm{N}_{2}$ value (obtained by Elemental Analyzer PE2400 Series II CHNS/O) by 6.25 according to Becker (1994). 


\section{Energy}

The energy content of biomass was determined as the summing of multiple the values obtained for protein, available carbohydrates and lipid by 4 . 00, 3.75 and 9. 00, respectively (Rebolloso Fuentes et al., 2000)

\section{Statistical analysis}

The concentration values were standardized to dry wt and data were analyzed using two-way analysis of variance (ANOVA), using COSTAT 2.0 statistical analysis software. Means were tested with least square difference (LSD), where the difference of $P \leq 0.01$ was highly significant. The mean value of triplicate data and the standard deviations (SD) were also calculated.

\section{Results}

\section{HA dose-response curves for a maximum of parameters:}

Biomass concentration: The growth of D. salina (Fig. 1) expressed as biomass concentration $\left(\mathrm{gL}^{-1}\right)$ showed a highly significant positive effect $(\mathrm{P} \leq 0.01)$ of HA concentration used up to the day 8 . The highest value $\left(3.9 \pm 0.3 \mathrm{gL}^{-1}\right)$ was observed in cells grown at $0.3 \mathrm{mgL}^{-1} \mathrm{HA}$. However, at the day 12 , a decline in the biomass was observed in cultures treated with 0.1 and $0.2 \mathrm{mgL}^{-1} \mathrm{HA}$, but the value was still higher than the control. Biomass concentration has been reduced to reach $42 \%$ and $33 \%$ of control value in 0.4 and $0.5 \mathrm{mgL}^{-1} \mathrm{HA}$ grown cells, respectively.

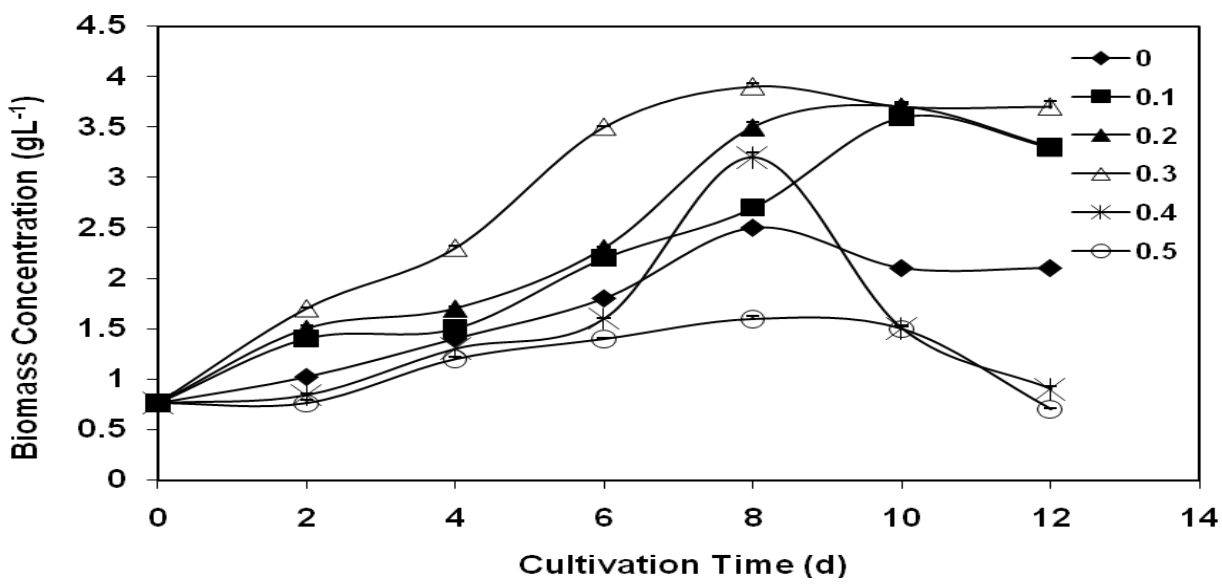

Figure (1): Growth response of $D$. salina to various humic acid concentrations. Values are means \pm SD $(n=3)$.

In $N$. salina, biomass concentration (Fig. 2) was gradually increased in $0.0,0.1,0.2$ and $0.3 \mathrm{mgL}^{-1} \mathrm{HA}$ grown cells up to the $10^{\text {th }}$ day. The highest value $\left(3.8 \mathrm{gL}^{-1}\right)$ was observed in cells grown at $0.2 \mathrm{mgL}^{-1} \mathrm{HA}$ on the days 8 and 10 . However, the biomass declined on $12^{\text {th }}$ day in all cultures but the biomass 
concentration in $0.1,0.2,0.3 \mathrm{mgL}^{-1} \mathrm{HA}$ grown cells were still higher than the control. Nevertheless, the biomass concentration has been reduced to $50 \%$ and $33 \%$ of control value at 0.4 and $0.5 \mathrm{mgL}^{-1} \mathrm{HA}$, respectively.

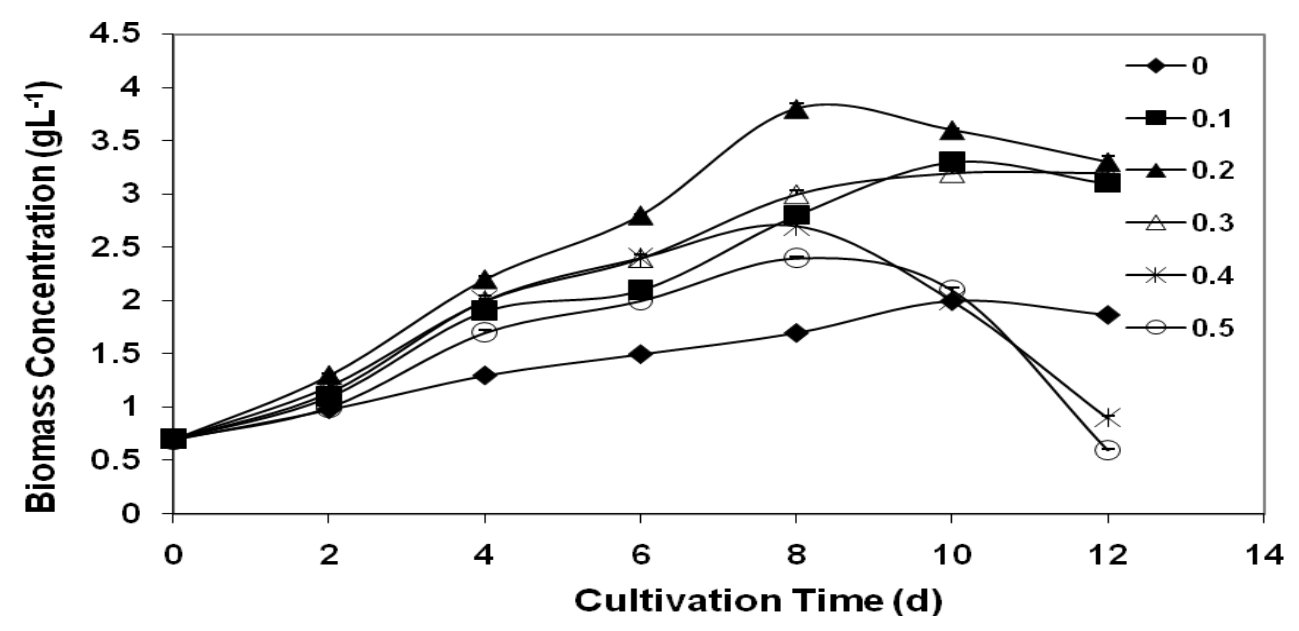

Figure (2): Growth response of $N$. salina to various humic acid concentrations. Values are means $\pm S D(n=3)$.

Chlorophyll a content in $D$. salina, chlorophyll a (Fig. 3) was gradually increased from $216.6 \pm 7$ to $372.46 \pm 1 \mathrm{mg} / 100 \mathrm{~g}$ dry wt at $0.2 \mathrm{mgL}^{-1} \mathrm{HA}$ treated cells, which represents a 1.72 fold. At $0.5 \mathrm{mgL}^{-1} \mathrm{HA}$, chlorophyll $a$ content decreased to reach approximately $48 \%$ of the control value. On the other hand, in $N$. salina, the content increased from $203.3 \pm 1$ to $340.9 \pm 3 \mathrm{mg} / 100 \mathrm{~g}$ dry wt., which represents a 1.67 fold of the control. At $0.5 \mathrm{mgL}^{-1} \mathrm{HA}$, chlorophyll $a$ declined to reach about $66 \%$ of the amount produced by control cells.

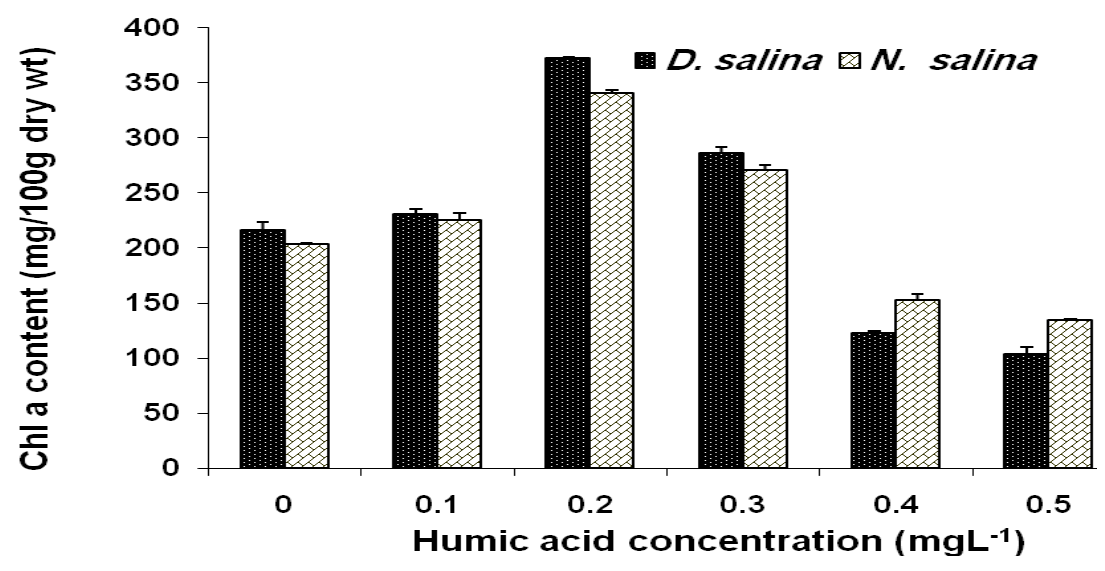

Figure (3): Standardized chlorophyll $a$ content of $D$. salina and $N$. salina in response to various HA concentrations. Values are means \pm SD $(n=3)$. 
Maximum carotenoid content (Fig. 4) of D. salina $(193.42 \pm 3 \mathrm{mg} / 100 \mathrm{~g}$ dry wt) was detected in cells grown at $0.1 \mathrm{mgL}^{-1} \mathrm{HA}$. While in $N$. salina, the maximum content $(214.24 \pm 8 \mathrm{mg} / 100 \mathrm{~g}$ dry wt) was observed in cells grown at $0.2 \mathrm{mgL}^{-1} \mathrm{HA}$. This content represents approximately 1.5 fold the content of the control value.

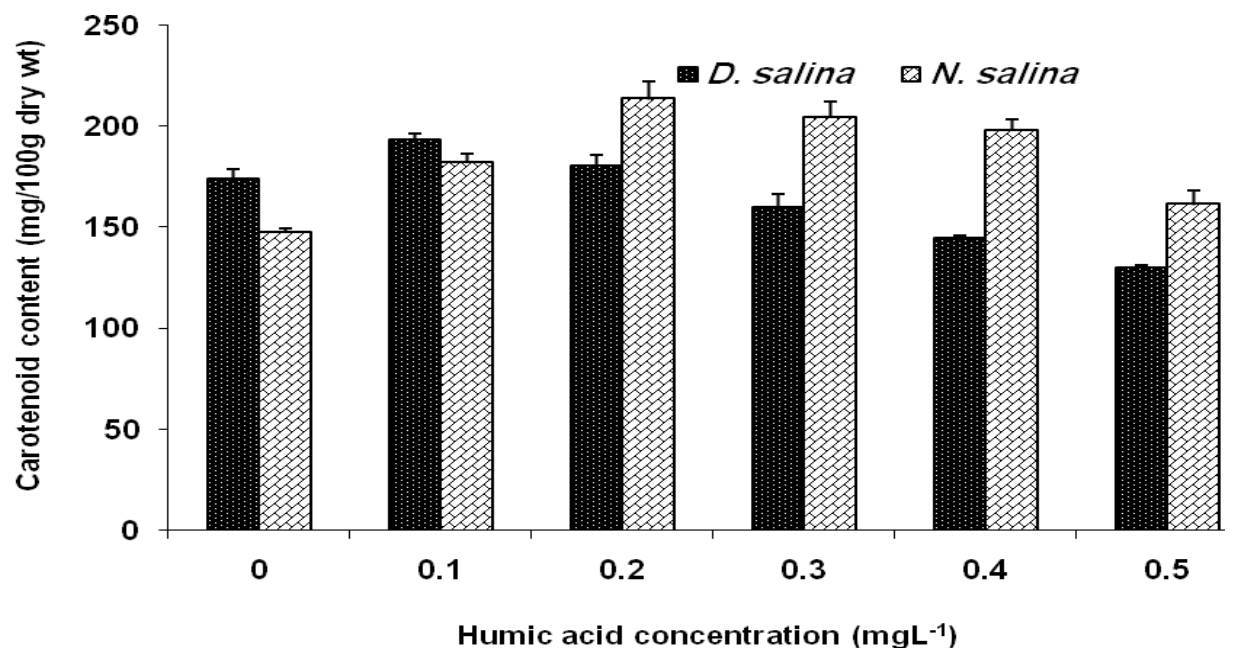

Figure (4): Standardized carotenoid content of $D$. salina and $N$. salina in response to various HA concentrations. Values are means \pm SD $(n=3)$.

In D. salina, $\mathrm{C} / \mathrm{N}$ value in control condition is recommended, but it gradually decreased with the impact addition of HA to reach its minimum value $(2.9 \pm 1)$ at $0.5 \mathrm{mgL}^{-1} \mathrm{HA}$. A result represents $0.32 \%$ of the control. However, in $N$. salina, a slight increase of the ratio was observed. Then the ratio has been reduced to $4.14 \pm 1$ at $0.5 \mathrm{~mL}^{-1} \mathrm{HA}$, (Fig. 5).

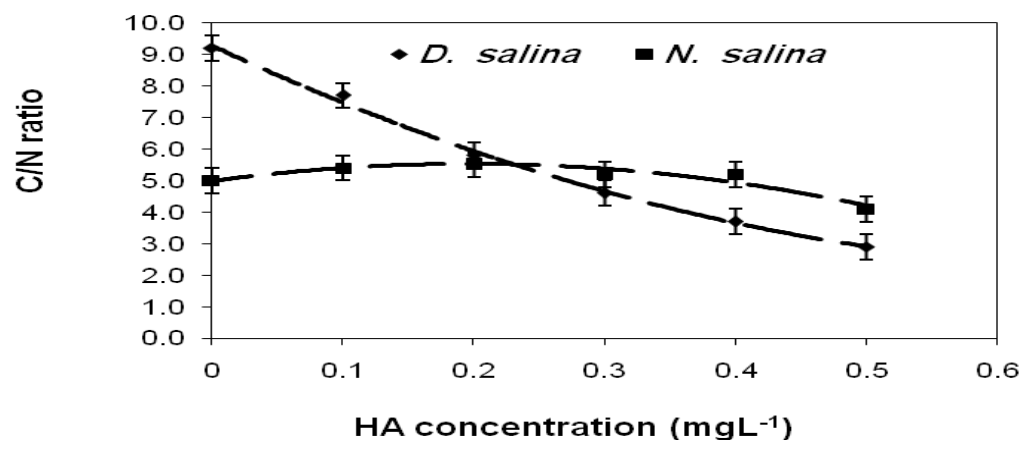

Figure (5): Impact of $\mathrm{HA}$ addition on $\mathrm{C} / \mathrm{N}$ ratio for $D$. salina and $N$. salina. Values are means \pm SD $(n=3)$. 


\section{HA impact on proximate composition:}

Data of proximate composition are shown in Table (1 and 2) in both microalgal species. Moisture content decreased in both microalgae upon the addition of HA concentrations up to $0.2 \mathrm{mgL}^{-1}$. This is followed by an increase $\left(6.0 \pm 0.1\right.$ and $7.2 \pm 0.3 \mathrm{~g} / 100$ dry wt) in $0.5 \mathrm{mgL}^{-1} \mathrm{HA}$ grown $D$. salina and $N$. salina, respectively.

Table 1: Impact of HA addition on proximate composition for $D$. salina (data are expressed as g/100g dry wt). Values are means $\pm \operatorname{SD}(n=3)$.

\begin{tabular}{cccccccc}
\hline $\begin{array}{c}\text { Humic acid } \\
\text { concentration } \\
\left(\mathrm{mgL}^{-1}\right)\end{array}$ & moisture & ashes & $\begin{array}{c}\text { Dietary } \\
\text { fibers }\end{array}$ & $\begin{array}{c}\text { Crude } \\
\text { lipid }\end{array}$ & $\begin{array}{c}\text { Available } \\
\text { carbohydrates }\end{array}$ & $\begin{array}{c}\text { Crude } \\
\text { protein }\end{array}$ & $\begin{array}{c}\text { Energy } \\
(\mathrm{KJ})\end{array}$ \\
\hline 0 & $1.7 \pm 0.1$ & $15 \pm 2$ & $0.38 \pm 1$ & $6.4 \pm 0.3$ & $20 \pm 3$ & $53.2 \pm 2$ & $1377 \pm 32$ \\
0.1 & $1.5 \pm 0.1$ & $3 \pm 0.2$ & $0.59 \pm 0.2$ & $8 \pm 0.5$ & $22 \pm 0.5$ & $59.9 \pm 2$ & $1649 \pm 39$ \\
0.2 & $1 \pm 0.1$ & $1 \pm 0.1$ & $0.49 \pm 1$ & $5.5 \pm 0.6$ & $23 \pm 0.4$ & $63 \pm 8$ & $1778 \pm 82$ \\
0.3 & $1.1 \pm 0.2$ & $2 \pm 0.1$ & $0.40 \pm 2$ & $5.1 \pm 0.7$ & $19.7 \pm 0.2$ & $66.4 \pm 8$ & $1734 \pm 41$ \\
0.4 & $1.8 \pm 0.3$ & $10.5 \pm 0.2$ & $0.30 \pm 0.2$ & $4.8 \pm 0.2$ & $18.4 \pm 3$ & $60.1 \pm 5$ & $1513 \pm 36$ \\
0.5 & $6 \pm 0.1$ & $27 \pm 0.2$ & $0.28 \pm 0.1$ & $4.2 \pm 0.2$ & $18.4 \pm 3$ & $44.3 \pm 6$ & $1226 \pm 29$ \\
\hline
\end{tabular}

The ash content in both microalgae showed a dramatic decrease at $0.1 \mathrm{HA}$ $\mathrm{mgL}^{-1}$ compared to the control value. However, at 0.4 and $0.5 \mathrm{HA}$ concentration, the ash content of both species underwent important increases that reached a 1.8 fold increase for D. salina and a 2.7 fold increase for $N$. salina in $0.5 \mathrm{mgL}^{-1} \mathrm{HA}$ grown cells.

Dietary fibers content in D. salina, increased from $0.38 \pm 1$ to $0.59 \pm 0.2$ $\mathrm{g} / 100 \mathrm{~g}$ dry wt at $0.1 \mathrm{mgL}^{-1} \mathrm{HA}$. Then the content was gradually decreased to reach its minimum value $(0.28 \pm 0.1)$ at $0.5 \mathrm{HA}$ concentration. However, in $N$. salina, HA addition bent a slight progressive increase of the fibers content from $0.59 \pm 0.3 \mathrm{~g} / 100 \mathrm{~g}$ dry wt to $0.70 \pm 0.3 \mathrm{~g} / 100 \mathrm{~g}$ dry wt in $0.5 \mathrm{mgL}^{-1} \mathrm{HA}$ grown cells.

Lipid content in D. salina increased upon the addition of $0.1 \mathrm{mgL}^{-1} \mathrm{HA}$ by 1.25 fold comparing to the control. However, at the higher HA concentrations, lipids were gradually reduced. A similar response was shown in $N$. salina, although the lipid content are relatively high comparing to $D$. salina. 
Humic acid stimulation of growth and optimization of biochemical profiles in two microalgal species........

Table 2: Impact of HA addition on proximate composition for $N$. salina (data are expressed as $\mathrm{g} / 100 \mathrm{~g}$ dry $\mathrm{wt})$. Values are means $\pm \mathrm{SD}(\mathrm{n}=3)$.

\begin{tabular}{cccccccc}
\hline $\begin{array}{c}\text { Humic acid } \\
\text { concentration } \\
\left(\mathrm{mgL}^{-1}\right)\end{array}$ & moisture & ashes & $\begin{array}{c}\text { Dietary } \\
\text { fiber }\end{array}$ & $\begin{array}{c}\text { Crude } \\
\text { lipid }\end{array}$ & $\begin{array}{c}\text { Available } \\
\text { carbohydrates }\end{array}$ & $\begin{array}{c}\text { Crude } \\
\text { protein }\end{array}$ & $\begin{array}{c}\text { Energy } \\
(\mathrm{KJ})\end{array}$ \\
\hline 0 (control) & $1.6 \pm 0.1$ & $12 \pm 0.4$ & $0.59 \pm 0.3$ & $9.2 \pm 0.1$ & $31 \pm 3$ & $39.89 \pm 0.5$ & $1500 \pm 35$ \\
0.1 & $1.4 \pm 0.1$ & $6 \pm 0.6$ & $0.59 \pm 0.3$ & $12 \pm 0.3$ & $33 \pm 3$ & $42.95 \pm 1$ & $1689 \pm 40$ \\
0.2 & $1.1 \pm 0.1$ & $4 \pm 0.6$ & $0.62 \pm 0.1$ & $9 \pm 0.4$ & $36 \pm 3$ & $44.36 \pm 1$ & $1731 \pm 61$ \\
0.3 & $2 \pm 0.1$ & $18.5 \pm 1$ & $0.69 \pm 0.1$ & $9 \pm 1.6$ & $26 \pm 0.2$ & $36.64 \pm 2$ & $1378 \pm 32$ \\
0.4 & $3.7 \pm 0.1$ & $20 \pm 2$ & $0.69 \pm 0.1$ & $8.5 \pm 1.5$ & $26 \pm 0.1$ & $33.63 \pm 4$ & $1291 \pm 30$ \\
0.5 & $7.2 \pm 0.3$ & $32 \pm 6$ & $0.70 \pm 0.3$ & $6 \pm 1.7$ & $14 \pm 0.1$ & $31.3 \pm 0.2$ & $969 \pm 23$ \\
\hline
\end{tabular}

Available carbohydrate was relatively low in both species grown at control condition comparing to other microalgae. It gradually increased with increasing HA dose to reach the maximum values $(23.0 \pm 0.4$ and $36.0 \pm 3.0)$ $\mathrm{g} / 100 \mathrm{~g}$ dry wt at $0.2 \mathrm{mgL}^{-1} \mathrm{HA}$ concentration for $D$. salina and $N$. salina respectively. At higher concentrations the values were declined, especially in $N$. salina to about half the amount of control.

Protein content was relatively high in most cultures of $D$. salina compared to other microalgae, the maximum value $(66.4 \pm 8 \mathrm{~g} / 100 \mathrm{~g}$ dry wt) was observed in cells grown in $0.3 \mathrm{mgL}^{-1} \mathrm{HA}$. On the other hand, in $N$. salina, the maximum value $(44.36 \pm 1 \mathrm{~g} / 100 \mathrm{~g}$ dry wt) was observed in cells grown at 0.2 $\mathrm{mgL}^{-1} \mathrm{HA}$.

Energy content was increased upon the addition of HA to reach its maximum value in $0.2 \mathrm{mgL}^{-1} \mathrm{HA}$ grown cultures. For $D$. salina, the maximum value was $1778 \pm 82$ (a $23 \%$ in excess of control), while for $N$. salina, the maximum value was $1731 \pm 61 \mathrm{KJ} / 100 \mathrm{~g}$ dry wt (a $15 \%$ in excess of control). However, D. salina showed a stronger response towards HA impact up to 0.4 $\mathrm{mgL}^{-1}$.

\section{Discussion}

Microalgae either as a full or partial enrichment should be considered for improving the nutritional quality of zooplankton. In this paper we simply reported the possible benefits of HA for the improvement the nutritional quality of the

Egyptian J. of Phycol. Vol. 8, $2007 \quad-21-$ 
studied microalgae. On the fact that the low concentration at which HA has their optimum effect is of economical interest.

The stimulatory capacity of HA on algal growth has been studied by many authors (Graneli et al., 1999; Gagnon et al., 2005; Sun et al., 2005). In the present study, the positive dose-response effect tends to decline at higher HA concentration.

The decline biomass concentration in both studied microalgae may be attributed to the ability of HS to complex trace elements in growth media. (Sunda and Huntsman, 1998) until they become limiting for cell growth (Gagnon et al., 2005).

Our results demonstrated a highly positive effect of HA $(P \leq 0.01)$ on the pigment production in both studied microalgae. A $0.2 \mathrm{mgL}^{-1} \mathrm{HA}$ showed maxima for chlorophyll $a$ in both species. Further, both investigated algae species are characterized by high carotenoid content at control condition (Fried, et al., 1982; Lubián et al., 2000). Ronnestad et al. (1998) demonstrated that microalgae pigments transferred through to zooplankton may contribute to nutritional value. They found that the dominant pigments in the copepod Temora sp. were lutein and astaxanthin, whereas in Artemia it was canthaxanthin. The present results are clearly demonstrated a positive role of HA on pigment production particularly in $N$. salina. Humic substances stimulated photosynthetic pigments in the green alga Pseudokirchneriella subcapitata (Koukal et al., 2003), and this stimulation is mainly depending on Fe bioavailability (Sun et al., 2005). As demonstrated by Brown (1969), Fe up take in Chlorella vulgaris was roughly proportional to the concentration of water-soluble humic acid in the nutrient medium.

$\mathrm{C} / \mathrm{N}$ ratio of $D$. salina grown in the absence of HA is close to the Redfield ratio and within the range expected for natural population. However, in N. salina, the ratio was relatively lower, but it is consistent with other previous studies (van Bleijswijk et al., 1994; Mohammady et al., 2005). C/N ratio depends mainly on the available carbohydrate content (Rebolloso Fuentes et al., 2000). In this study, the gradual decrease of $\mathrm{C} / \mathrm{N}$ ratio in $D$. salina or the slight increase in $N$. salina upon HA addition is probably related to either the low amount of available carbohydrates or a high nitrogen content of the cells. Otherwise, both reasons may collectively lead to this result in both microalgae. $\mathrm{C} / \mathrm{N}$ ration varies by almost a factor of four in D. salina, while the available carbohydrates undergo a small 1.1 fold reduction. In relation to the considered rigid cell wall of $N$. salina which could contain non-soluble polysaccharides on which the HS could have a more important impact.

A variation in moisture content upon addition of HA was observed in both microalgae in conflicting trend to biomass concentration. However, the values ranged in generally recommended (less than 10\%) in nutritional purposes (Becker, 1994). 
High ash content in cultures grown under control condition was consistent with other studies on marine microalgae (Markovits et al., 1991; Canizares et al., 1994) and differs from that of the fresh water algae, Scnedesmus and Spirulina (Becker and Venkataraman, 1982). The addition of low HA concentration caused a decrease in ash content in both microalgae species. However, with the impact addition, the ash has been increased. The excess ash content upon increasing of HA concentration may be attributed to increase in cell permeability (Vigneault et al., 2000) with respect to the electrogenic proton pump (Visser, 1985). This leads to an increase in the nutrient uptake (Legrand and Carlsson, 1998). The incineration of these nutrients may lead to (left) yield an approximately two fold the ash amount in D. salina and more than 2.5 fold in $N$. salina comparing to their yield at control condition.

Low fiber content in D. salina, comparing to N. salina, may be attributed to the absence of the rigid cell wall in the organism. Generally, the content is recommended as a low in both tested microalgae suggesting a more easily digestible biomass in nutritional purposes (Rebolloso Fuentes et al., 2000).

At control condition, the low lipid content in both investigated microalgae may be attributed to the harvesting of culture at the logarithmic growth phase (Piorreck and Pohl, 1984). However, upon $0.1 \mathrm{mgL}^{-1} \mathrm{HA}$ addition, the value was raised by 1.25 and $1.30 \mathrm{~g} / 100 \mathrm{~g}$ dry wt. for D. salina and N. salina respectively. As well known, HS has a negative effect on the cellular membranes. The reason explains the reduction of lipid content with increasing HA dose in both investigated species.

The content of available carbohydrates was relatively low in cultures grown at control condition. The values showed maxima upon the impact of 0.02 $\mathrm{mgL}^{-1} \mathrm{HA}$, but it still low comparing to other studies. As explained by Rebolloso Fuentes et al. (2000), the low available carbohydrate content is a result of washing biomass.

Proteins are the fundamental building blocks for tissue biosynthesis and enzyme production in all animals. Thus, protein must meet these demands for tissue production and metabolic processes (Gatenby et al., 2003). Protein is generally considered most important to the rapidly growing Juvenile life stage, followed by adults undergoing gametogenesis (Kreeger and Langdon, 1993; Fernández Sevilla, 1995). In this study, both algae species are characterized by high protein content at the control conditions, particularly $D$. salina. An obvious increase in protein production $\left(25 \%\right.$ excess in $D$. salina grown at $0.3 \mathrm{mgL}^{-1} \mathrm{HA}$ and $13 \%$ excess in $N$. salina grown at $0.2 \mathrm{mgL}^{-1} \mathrm{HA}$ ) was detected. As postulated by Chen and Aviad (1990), HA increase nitrate uptake from the nutrient medium which in turn increases the structural proteins inside the cell. However, the declined data may be due to the impact of HA for forming complexes with amino acids, peptides and steroids (Frimmel and Christman, 1988). 
Energy is a property of nutrients that is released of metabolic oxidation of protein, lipid and carbohydrates. As an abstract result, the energy potential of biomass was increased in response to HA addition. The maximum value for both algae species was recorded in cells grown at $0.2 \mathrm{mgL}^{-1} \mathrm{HA}$, indicating unlike response towards their oxidation process. However, all energy values are recommended (Whyte, 1987) for aquaculture purposes.

In conclusions: Our main objective was to evaluate the stimulatory potential of $\mathrm{HA}$ on the biomass, pigment production, proximate analysis and $\mathrm{C} / \mathrm{N}$ ratio. The results of the present experiments clearly demonstrated this potential.

The response of the both investigated microalgal species to HA concentration showed optima in the range of concentration studied in the sub-mg per liter range which makes it a low cost-high yield investment. On the fact that the low concentration at which HA has their optimum effect is of economical interest.

Finally, we recommend the addition of HA, as a supplement in the nutrient media of the studied microalgae, as a biostimulator for their nutritional composition particularly in aquaculture industry.

\section{Acknowledgements}

I greatly appreciate efforts of Dr. Réal Gagnon, Maurice Lamontagne Institute, Department of Fishries and Oceans Canada, for his revision of this paper and valuable advices.

\section{References}

Becker, E. W. (1994). Microalgae biotechnology and microbiology. Cambridge University Press, UK.

Becker, E. W. and Venkataraman, L. V. (1982). Biotechnology and exploitation of algae-the Indian approach. Eschborn: German Agency for Technical Cooperation.

Boussiba, S.; Vonshak, A.; Chohen, Z.; Avissar, Y. A. and Richmond, A. (1987). Lipid and Biomass production by halotolerant microalga Nannochloropsis salina. Biomass, 12:17-24.

Brown, C. J. (1969). Effect of coal derived humic acid on growth and chlorophyll content of Chlorella vulgaris. M. S. Thesis, U. of North Dakota, USA., pp. 35.

Brown, M. R. (2002). Nutritional value and use of microalgae for aquaculture. In: Cruz-Suárez L. E., Ricque-Marie D., Tapia-Salazar M., Gaxiola-Cortés M. G., Simoes N. (Eds.). Avances en Nutrición Acuicola VI. Memorias del VI Simposium Internacional de Nutrición Acuicola. 3 al 6 de Septiembre del 2002. Cancú, Quintana Roo, México.

Brown, M. R.; Jeffrey, S. W.; Volkman, J. K. and Dunstan, G. A. (1997). Nutritional properties of microalgae for mariculture. Aquaculture, 151: 315-331. 
Canellas, L. P.; Olivares, F. L.; Okorokova-Facanha, A. L. and Facanha, A. R. (2002). Humic acids isolated from Earthworm compost enhance root elongation, lateral root emergence, and plasma membrane $\mathrm{H}^{+}$-ATP ase activity in Maize roots. Plant Physiol., 130:1951-1957.

Canizares, R. O.; Molina, G. and Dominguez, A. R. (1994). Compositión quimica de dos microalgas marinas utilizadas como alimento en maricultura. Cryptogamie Algologie, 15:121-133.

Carlsson, P.; Granéli, E.; Tester, P. and Boni, L. (1995). Influences of riverine humic substances on bacteria, protozoa, phytoplankton and copepods in a coastal plankton community. Mar. Ecol. Prog. Ser., 127:213-221.

Chen, Y. and Aviad, T. (1990). Effects of humic substances on plant growth. In Humic Substances in Soil and Crop Science: Selected Readings. MacCarthy P, Clapp C E, Malcolm R L, Bloom P R (eds) Pp. 161-186, American Society of Agronomy Inc., Soil Science of America, Inc., Madison, WI., USA.

Coates, J. D.; Cole, K. A.; Chakraborty, R.; O'Connor, S. M. and Achenbach, L. A. (2002). Diversity and Ubiquity of bacteria capable of utilizing humic substances as electron donors for anaerobic respiration. Appl. Environ. Microbiol., 67:2445-2452.

Doblin, M. A.; Blackburn, S. I. and Hallegraeff, G. M. (2000). Intraspecific variations of the toxic dinoflagellate Gymnodinium catenatum. J. Plankton Res., 22: 421-432.

Doblin, M. A.; Blackburn, S. I. and Hallegraeff, G. M. (1999). Growth and biomass stimulation of the toxic dinoflagellate Gymnodinium catenatum (Graham) by dissolved organic substances. J. Exp. Mar. Biol. Ecol., 236: 33-47.

Fabregas, J. and Herrero, C. (1986). Marine microalgae as a potential source of minerals in fish diets. Aquaculture, 51: 237-243.

Fernández Sevilla, J. M. (1995). Estudio del crecimientno simultáneo fotolimitado y fotoinhibido de la microalga marina Isocrysis galbana. Productividad en ácidos grasos polinsaturados n-3. Ph D. Thesis. Universidad de Alemeria.

Fried, A.; Tietz, A.; Ben-Amotz, A. and Einchenberger, W. (1982). Lipid composition of the halotolerant alga Dunaliella bardawil. Biochem. Biophys. Acta, 713:419-420.

Frimmel, F. H. and Christman, R. F. (1988). Humin substances and their role in the environment. $1^{\text {st }}$ ed. Vol. 1, Wiley-Interscience Publication, New York, USA. 
Gagnon, R.; Evasseur, M.; Weise, A. M.; Fauchot, J.; Campbell, P. G. C.; Weissenboeck, B. J.; Merzouk, A.; Gosselin, M. and Vigneault, B. (2005). Growth stimulation of Alexandrium Tamarense (Dinophyceae) by humic substances from the Manicouagan River (Eastern Canada). $J$. Phycol., 41: 489-497.

Gatenby, C. M.; Orcutt, D. M.; Kreeger, D. A.; Bruce, C. P.; Jones, V. J. and Neves, R. J. (2003). Biochemical composition of three algal species proposed as food for captive freshwater mussels. J. Appl. Phycol., 15:1-11.

Goering, H. K. and Van Soest, P. J. (1970). Forage fiber analysis. Handbook no. 379. Washington DC: US Department of Agriculture, USA.

Granéli, E.; Carlsson, P. and Legrand, C. (1999). The role of C, N and P in dissolved and particular organic matter as a nutrient source for phytoplankton growth including toxic species. Aquat. Ecol., 33:17-27.

Hansmann, E. (1973). Pigment analysis. In Handbook of phycological methods, culture methods and growth measurements. Stein J R (editor), London, Cambridge University Pres, PP. 359-368.

Kochert, G. (1978). Quantification of the macromolecular components in microalgae. In Handbook of Phycological methods. Physiological and biochemical methods Hellebust J, Cragie S (eds), London, Cambridge University Press, PP. 189.

Koukal, B.; Gueguen, C.; Pardos, M. and Dominik. J. (2003). Influence of humic substances on the toxic effects of cadmium and zinc to the green alga Pseudokirchneriella subcapitata. Chemosphere, 53:953-961.

Kreeger, D. A. and Langdon, C. J. (1993). Effect of dietary protein content on growth of juvenile mussels Mytilus trossulus (Gould 1850). Biol. Bull., 185:123-129.

Legrand, C. and Carlsson, P. (1998). Uptake of high molecular weight dextran by the dinoflagellate Alexandrium catenella. Aquat. Micob. Ecol., 16: 8186.

Loeblich, L. A. (1982). Photosynthesis and pigments influenced by light intensity and salinity in the halophilic Dunaliella salina (Chlorophyta). J. Mar. Biol. Ass.UK,62:493-508.

Lubián, L. M.; Montero, O.; Garrido-Moreno, I.; Huertas, E.; Sobrino, C.; Gonzalez-Delvalle, M. and Pares, G. (2000). Nannochloropsis (Eustigmatophyceae) as a source of commercially valuable pigments. J. Appl. Phycol., 12: 249-255.

Mackowiak, C. L.; Grossi, P. R. and Bugbee, B. G. (2001). Beneficial effects of humic acid on micronutrient availability to wheat. Soil Sci. Soc. Am. J., 65:1744- 1750 . 
Markovits, A.; López, L.; Costa, E. and Lutz, M. (1991). Microalgas como Alimento Humano Potencial (I). Evaluacion quimica y Biológica de phaedocthylum tricornutum. Alimentación Equipos y Tecnologia., 87:119123.

Mirón, A. S.; Garcia, C.; Camacho, F. G.; Grima, E. M. and Chisti, Y. (2002). Growth and biochemical characterization of microalgal biomass produced in bubble column and airlift photobioreactors: studies in fedbatch culture Enzyme. Microb. Technol., 31:1015-1023.

Mohammady, N.G. and Fathy, A. A. (2007). Humic acid mitigates viability reduction, lipids and fatty acids of Dunaliella salina and Nannochloropsis salina grown under nickel stress. Int. J. Bot., 3:64-70.

Mohammady, N. G.; Chen, Y.C.; El-Mahdy, A. and Mohammad, R. F. (2005) Physiological responses of eustigmatophycean Nannochloropsis salina to aqueous diesel fuel pollution. Oceanologia, 47:75-92.

Mohammady, N. G. (2004). Total, free and conjugated sterolic forms in three microalgae used in mariculture. Z. Naturforsch., 59:619-624.

Muller-Wegener, U. (1988). Interaction of humic substances with biota. In Humic substances and their role in the Environment, Frimmel $\mathrm{F} \mathrm{H}$, Christman R F (eds) John Wiley and Sons, New York, USA., pp. 179-193.

Osborne, D. R. (1985). Análisis de Nutrientes de los Alimentos. Zaragoza Acribia, pp.136-153.

Piorreck, M. and Pohl, P. (1984). Formation of biomass, total protein, chlorophylls, lipids and fatty acids in green and blue green algae during one growth phase. Phytochemistry, 23:217-223.

Rebolloso Fentes, M. M.; Acién Fernández, G. G.; Sánchez Pérez, J. A and Guil Guerrero, J. L. (2000). Biomass nutrient profiles of the microalga Porphyridium cruntum. Food Chemistry, 70:345-353.

Renaud, S. M.; Thinh, L. V. and Parry, D. L. (1999). The gross composition and fatty acid composition of 18 species of tropical Australian microalgae for possible use in mariculture. Aquaculture, 170:147-159.

Ronnestad, I.; Hellad, S. and Lie, O. (1998). Feeding Artemia to larvae of Atlantic halibut (Hippoglossus hippoglossus L.) results in lower larval vitamin A content compared with feeding copepods. Aquaculture, 165: 159-164.

Sargent, J. R.; McEvoy, L. A. and Bell, J. G. (1997). Requirements, presentation and sources of polyunsaturated fatty acids in marine fish larval feeds. Aquaculture, 155:117-127.

Stevenson, F. (1982). Humus chemistry: genesis, composition, reactions. John Wiley and Sons, New York, USA.

Sukenik, A.; Carmeli, Y. and Berner, T. (1989). Regulation of fatty acid composition by irradiance level in the eustigmatophyte Nannochloropsis sp. J. Phycol., 125: 686-692. 
Sun, B. K.; Tanji, Y. and Unno, H. (2005). Influences of iron and humic acid on the growth of the cyanobacterium Anabaena circinalis. Biochem. Eng. J., 24:195-201.

Sunda, W. G. and Huntsman, S. A. (1998). Processes regulating cellular metalaccumulation and physiological effects: phytoplankton as model systems. Sci. Total Environ., 219:2-3.

Van Bleijswijk, J. D. L.; Kempers, R. S.; Veldhuis, M. J. and Westbroek, P. (1994). Cell and growth characteristics of type A and type B of Emiliania huxleyi (Prymnesiophyceae) as determined by flow cytometry and chemical analyses. J. Phycol., 30:230-241.

Veloza, A. J.; Chu, F-L. E and Tang, K. W. (2006). Trophic modification of essential fatty acids by hetertrophic protests and its effects on the fatty acid composition of the copepods Acartia tonsa. Mar. Biol., 148:779-788.

Vigneault, B.; Percot, A.; Lafleur, M. and Campbell, P. G. C. (2000). Permeability changes in model and phytoplankton membranes in the presence of aquatic humic substances. Environ. Sci. Technol., 34:39073913.

Visser, S. A. (1985). Physiological action of humic substances on microbial cells. Soil Biol. Biochem., 17:457-462.

Whyte, J. C. (1987). Biochemical composition and energy content of six species of phytoplankton used in mariculture of bivalves. Aquaculture, 60: 231241.

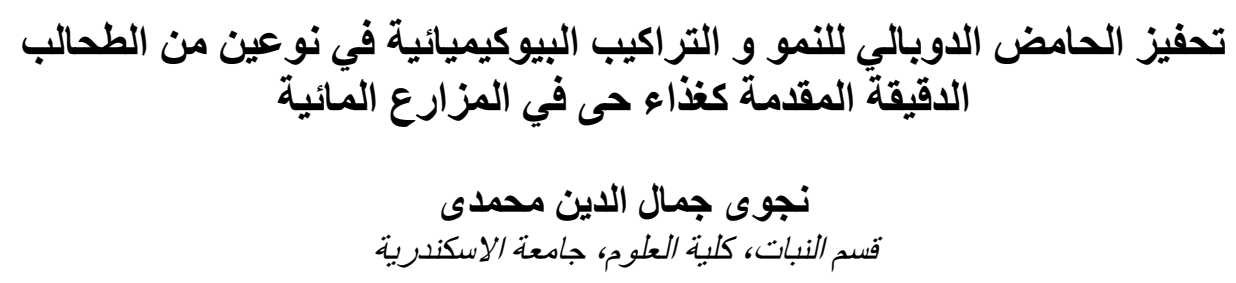

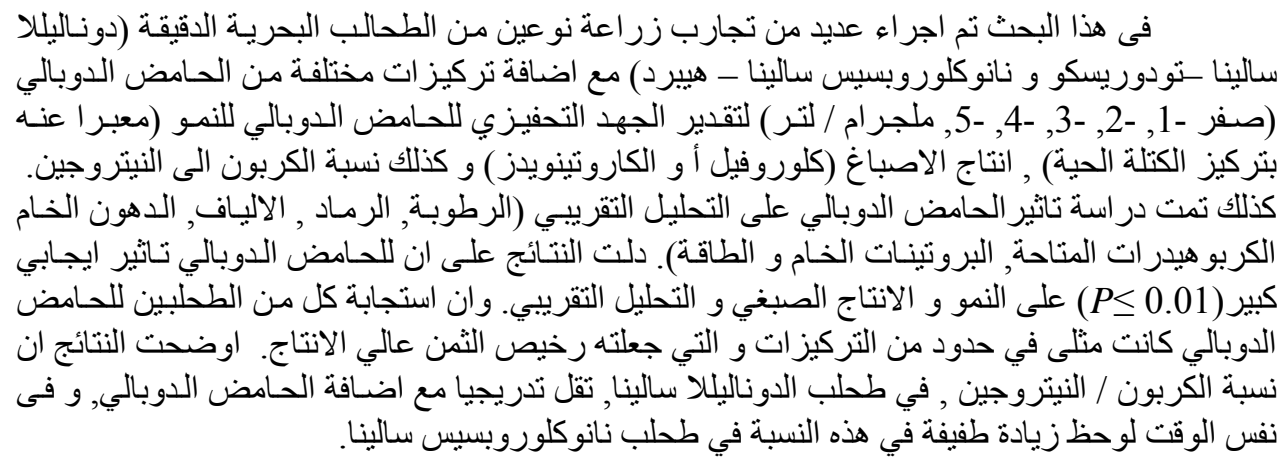

Egyptian J. of Phycol. Vol. 8, $2007 \quad 28$ - 